\title{
Article \\ Dipeptides of $S$-Substituted Dehydrocysteine as Artzyme Building Blocks: Synthesis, Complexing Abilities and Antiproliferative Properties ${ }^{\dagger}$
}

\author{
Paweł Lenartowicz ${ }^{1, *} *$, Mateusz Psurski ${ }^{2}\left(\mathbb{D}\right.$, Aleksandra Kotynia ${ }^{3}$, Aleksandra Pieniężna ${ }^{3}$, Monika Cuprych $^{2}(0$, \\ Klaudia Poniatowska ${ }^{2}$, Justyna Brasun ${ }^{3}$ and Paweł Kafarski ${ }^{4, *}$ (i) \\ 1 Faculty of Chemistry, University of Opole, ul. Oleska 48, 45-052 Opole, Poland \\ 2 Laboratory of Experimental Anticancer Therapy, Hirszfeld Institute of Immunology and Experimental \\ Therapy, Polish Academy of Sciences, ul. R. Weigla 12, 53-114 Wrocław, Poland; \\ mateusz.psurski@hirszfeld.pl (M.P.); monika.cuprych@hirszfeld.pl (M.C.); k.poniatowska96@gmail.com (K.P.) \\ 3 Department of Inorganic Chemistry, Wrocław Medical University, ul. Borowska 211 A, 50-556 Wrocław, \\ Poland; aleksandra.kotynia@umed.wroc.pl (A.K.); aleksandra.pieniezna@umed.wroc.pl (A.P.); \\ justyna.brasun@umed.wroc.pl (J.B.) \\ 4 Department of Bioorganic Chemistry, Wrocław University of Science and Technology, \\ Wybrzeże Wyspiańskiego 27, 50-370 Wrocław, Poland \\ * Correspondence: pawel.lenartowicz@uni.opole.pl (P.L.); pawel.kafarski@pwr.edu.pl (P.K.) \\ + This article is dedicated in honour of Professor Lechosław Latos-Grażyński on his 70th birthday.
}

check for updates

Citation: Lenartowicz, P.; Psurski, M.; Kotynia, A.; Pieniężna, A.; Cuprych, M.; Poniatowska, K.; Brasuń, J.; Kafarski, P. Dipeptides of S-Substituted Dehydrocysteine as Artzyme Building Blocks: Synthesis, Complexing Abilities and Antiproliferative Properties . Int. J. Mol. Sci. 2021, 22, 2168. https://doi. org/10.3390/ijms22042168

Academic Editor: Paula A. C. Gomes

Received: 30 January 2021

Accepted: 18 February 2021

Published: 22 February 2021

Publisher's Note: MDPI stays neutral with regard to jurisdictional claims in published maps and institutional affiliations.

Copyright: (c) 2021 by the authors. Licensee MDPI, Basel, Switzerland. This article is an open access article distributed under the terms and conditions of the Creative Commons Attribution (CC BY) license (https:/ / creativecommons.org/licenses/by/ $4.0 /)$.

\begin{abstract}
Background: Dehydropeptides are analogs of peptides containing at least one conjugate double bond between $\alpha, \beta$-carbon atoms. Its presence provides unique structural properties and reaction centre for chemical modification. In this study, the series of new class of dipeptides containing $S$-substituted dehydrocysteine with variety of heterocyclic moieties was prepared. The compounds were designed as the building blocks for the construction of artificial metalloenzymes (artzymes). Therefore, the complexing properties of representative compounds were also evaluated. Furthermore, the acknowledged biological activity of natural dehydropeptides was the reason to extend the study for antiproliferative action of against several cancer cell lines. Methods: The synthetic strategy involves glycyl and phenylalanyl-(Z)- $\beta$-bromodehydroalanine as a substrate in one pot addition/elimination reaction of thiols. After deprotection of $\mathrm{N}$-terminal amino group the compounds with triazole ring were tested as complexones for copper(II) ions using potentiometric titration and spectroscopic techniques (UV-Vis, CD, EPR). Finally, the antiproliferative activity was evaluated by sulforhodamine B assay. Results and Conclusions: A simple and efficient procedure for preparation of dipeptides containing $S$-substituded dehydrocysteine was provided. The peptides containing triazole appeared to be strong complexones of copper(II) ions. Some of the peptides exhibited promising antiproliferative activities against number of cancer cell lines, including cell lines resistant to widely used anticancer agent.
\end{abstract}

Keywords: dehydrocysteine; dehydropeptides; addition-elimination reaction; complexing agent; antiproliferative activity

\section{Introduction}

Nature utilizes twenty amino acids set to generate an array of proteins with diverse structures and functions. Amongst them are extremely efficient catalysts in living organisms-enzymes. Despite of that, there is a large number of enzymes there are also some reactions with not known enzymatic equivalent. Thus, the premise of constructing enzyme-like catalysts, which are capable of efficient catalysis of virtually any chemical reaction is a tremendous challenge. It is not surprising that intensive efforts have been undertaken to obtain enzyme mimetics and that various strategies of their design have been described [1-4]. Such bioinspired catalysts are broadly termed artificial enzymes or 
"artzymes" [3,5,6]. One class of these molecules is constructed in such a manner that the peptide folds (in most cases foldamer helical segments) guarantee specific architecture of the catalyst, while amino acids side chain structures are responsible for the enzyme-like activity [7-12]. This allows to construct catalytic active sites not seen in nature. Such artzymes are commonly constructed by the stepwise joining of small peptide units (most likely foldamers) of variable sequences [13-16].

The main goal of the project is the synthesis of dipeptides designed as building blocks of foldamers to be further exploited in artzyme preparation. For that, functionalization of peptides containing $C$-terminal dehydroalanine with heterocyclic thiols, leading to $S$ substituted dehydrocysteine derivatives was chosen as a first approach. The obtained peptides are designed for the construction of mimetics of metallo-enzymes. Thus, we have checked whether the chosen representatives possess abilities to complex copper(II) ions. Since some dehydropeptides are known as natural biologically active compounds and exhibit antibiotic, antifungal, antitcancer, phytotoxic and antiproliferative activity $[17,18]$ we had decided to extend our study towards the evaluation of the antiproliferative activity of the obtained compounds against several cancer cell lines.

\section{Results and Discussion}

\subsection{Syntheses}

Thiols readily underwent Michael addition to $N$-protected glycyl-dehydroalanine (compound 1) and phenyl-dehydroalanine (compound 2) providing micromolar inhibitors of cathepsin C [19]. Thus, the first approach in this work was to use this reaction for the synthesis of the desired peptides containing C-terminal cysteine $S$-functionalized with various heterocycles (compounds 3; Scheme 1a). Surprisingly this approach appeared to be completely unsuccessful.

a)

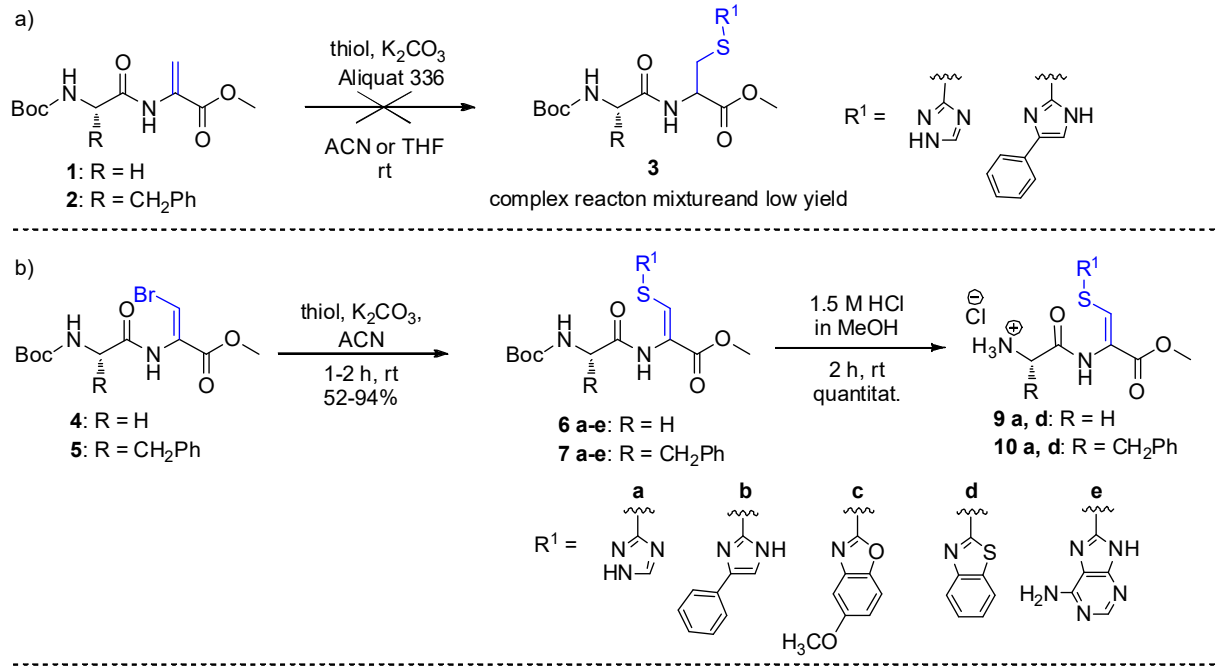

c)

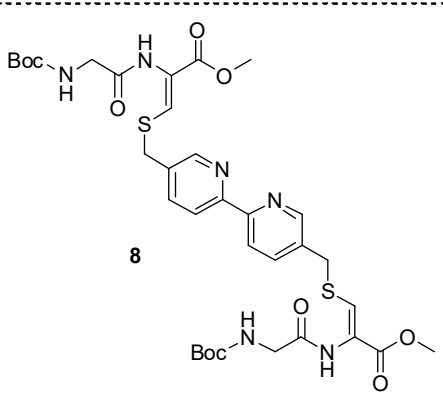

Scheme 1. Syntheses of dipeptide building blocks containing (a) C-terminal cysteines; (b) C-terminal dehydrocysteines; (c) cross-linked dehydrocysteines. 
Recently we had found that the addition of bromine to compounds $\mathbf{1}$ and $\mathbf{2}$, followed by elimination of the bromine atom by the action of triethylamine provided dehydropeptides 4 and 5 containing ( $Z$ )- $\beta$-bromodehydroalanine [20]. These peptides by being crystalline and stable upon storage had been considered as ideal substrates for addition-elimination reaction and provided readily a series of dehydropeptides (compounds 6 and 7; Scheme 1b). The whole procedure is simple and results in the desired dehydropeptides in good yields (Table 1).

Table 1. The yield of synthesised compounds.

\begin{tabular}{|c|c|c|}
\hline $\begin{array}{c}\text { Compound } \\
\text { No. }\end{array}$ & Name Abbreviation & $\begin{array}{c}\text { Isolated Yield } \\
{[\%]}\end{array}$ \\
\hline $6 a$ & Boc-Gly- $\Delta$ Cys(S-triazole)-OMe & 93 \\
\hline $7 \mathbf{a}$ & Boc-Phe- $\Delta$ Cys (S-triazole)-OMe & 94 \\
\hline $6 b$ & Boc-Gly- $\Delta$ Cys (S-4-phenylimidazole)-OMe & 93 \\
\hline $7 \mathbf{b}$ & Boc-Phe- $\Delta$ Cys (S-4-phenylimidazole)-OMe & 86 \\
\hline $6 c$ & Boc-Gly- $\Delta$ Cys(S-5-methoxybenzoxazole)-OMe & 90 \\
\hline $7 \mathrm{c}$ & Boc-Phe- $\Delta$ Cys(S-5-methoxybenzoxazole)-OMe & 76 \\
\hline $6 \mathrm{~d}$ & Boc-Gly- $\Delta$ Cys (S-benzothiazole)-OMe & 82 \\
\hline $7 \mathrm{~d}$ & Boc-Phe- $\Delta$ Cys(S-benzothiazole)-OMe & 92 \\
\hline $6 e$ & Boc-Gly- $\Delta$ Cys (S-adenine)-OMe & 61 \\
\hline $7 e$ & Boc-Phe- $\Delta$ Cys( $S$-adenine)-OMe & 52 \\
\hline 8 & Boc-Gly- $\Delta$ Cys(S,S-bismethylbipyridine)-OMe & 80 \\
\hline 9a & $\mathrm{HCl}$ Gly- $\Delta \mathrm{Cys}(S$-triazole)-OMe & [a] \\
\hline $10 a$ & $\mathrm{HCl}$ Phe- $\Delta$ Cys $(S$-triazole)-OMe & [a] \\
\hline 9d & $\mathrm{HCl}$ Gly- $\Delta \mathrm{Cys}(S$-benzothiazole)-OMe & [a] \\
\hline $10 \mathrm{~d}$ & $\mathrm{HCl}$ Phe- $\Delta$ Cys( $S$-benzothiazole)-OMe & [a] \\
\hline
\end{tabular}

[a] The product obtained quantitatively.

Additionally, we have used 5,5-bis(mercaptomethyl)-2,2'-bipyridine as a substrate and obtained product crosslinking of the two peptide chains (Boc-Gly- $\Delta \mathrm{Cys}(S, S$-bismethyl bipyridine)-OMe, compound 8, Scheme 1c). Removal of Boc-protection from four representative examples of the obtained dehydropeptides by using the solution of hydrochloride in methanol resulted in the preparation of compounds 9 and $\mathbf{1 0}$ (Scheme 1b). The stereochemistry of the obtained peptides was assigned as $Z$, basing on NMR studies (for details please see Supplementary Materials).

It is worth to mention, that this simple synthetic protocol enables to incorporate aliphatic and aromatic thiols into the structure of a peptide. Therefore, this reaction seems also to be useful in late-stage functionalisation of peptides. According to our knowledge, the designed dehydrocysteine derivatives have not equivalent in naturally occurring dehydropeptides. Cysteine could rather be converted to dehydroalanine by elimination reaction. The incorporation of heterocyclic moiety into the side chain of dehydrocysteines is rarely described $[21,22]$ and this modification should affect the biological and coordination properties o dehydropeptides.

\subsection{Complexation of $\mathrm{Cu}^{2+}$ Ions by Compounds $9 \mathbf{a}$ and 10a}

Fully blocked peptides 6 and 7 appeared to be very weak complexones for $\mathrm{Cu}^{2+}$ ions. This is probably because there is a lack of moiety anchoring copper(II) ions. On the contrary, their unblocked counterparts, compounds 9 and 10, appeared to be quite effective complexones. The characteristic feature of the dehydropeptides containing $S$-substituted (Z)-dehydrocysteines is their very rigid structure and low flexibility.

Being the structurally simplest representatives, compounds 9a and 10a have been chosen for a more detailed study of complexation mode. Both studied ligands are characterized by three protonation constants (Table 2). The logK values of 7.96 (for 9a) and 8.11 (for 10a) are typical for the constants related to the free $N$-terminal amino group in short peptides [23-27]. The next two constants $(\log K \approx 10.3$ and $\approx 7.0)$ result from the presence of 
the 1,2,4-triazole ring, however, they are significantly higher in comparison to the constants found for the free triazole ring $(\log K \approx 9.5$ and $\approx 2.5)$ [28-30]. This may be explained by the possible formation of the intramolecular hydrogen bond between one of the triazole protons and the oxygen atom from the neighboring peptide bond (Figure 1).

Table 2. The protonation constants of free ligands and stability constants of formed $\mathrm{Cu}(\mathrm{II})$-complexes. The errors are represented by $\pm \mathrm{SD}$.

\begin{tabular}{|c|c|c|c|c|}
\hline \multirow[b]{2}{*}{ Form } & \multicolumn{2}{|c|}{$9 a$} & \multicolumn{2}{|c|}{$10 a$} \\
\hline & $\log \beta$ & $\log K$ & $\log \beta$ & $\log K$ \\
\hline & \multicolumn{4}{|c|}{ The protonation constants of free ligands } \\
\hline $\mathrm{H}_{3} \mathrm{~L}$ & $25.31 \pm 0.01$ & 7.26 & $25.38 \pm 0.02$ & 6.85 \\
\hline $\mathrm{H}_{2} \mathrm{~L}$ & $18.05 \pm 0.01$ & $7.96\left(-\mathrm{NH}_{2}\right)$ & $18.53 \pm 0.02$ & $8.11\left(-\mathrm{NH}_{2}\right)$ \\
\hline HL & $10.09 \pm 0.01$ & 10.09 & $10.42 \pm 0.01$ & 10.42 \\
\hline & \multicolumn{4}{|c|}{ The stability constants of $\mathrm{Cu}(\mathrm{II})$-complexes } \\
\hline $\mathrm{CuLH}_{2}$ & $23.52 \pm 0.03$ & 9.34 & $23.83 \pm 0.03$ & 8.83 \\
\hline $\mathrm{CuL}$ & $14.18 \pm 0.01$ & 10.42 & $15.00 \pm 0.01$ & 10.61 \\
\hline $\mathrm{CuLH}_{-1}$ & $3.76 \pm 0.04$ & - & $4.39 \pm 0.03$ & - \\
\hline $\mathrm{Cu}_{2} \mathrm{~L}_{2} \mathrm{H}$ & $36.61 \pm 0.03$ & 14.45 & $37.54 \pm 0.06$ & 14.59 \\
\hline $\mathrm{Cu}_{2} \mathrm{~L}_{2} \mathrm{H}_{-1}$ & $22.16 \pm 0.06$ & - & $22.95 \pm 0.06$ & - \\
\hline $\mathrm{CuL}_{2} \mathrm{H}_{2}$ & $36.46 \pm 0.04$ & 7.67 & - & - \\
\hline $\mathrm{CuL}_{2} \mathrm{H}$ & $28.79 \pm 0.04$ & 8.73 & $28.82 \pm 0.11$ & 8.45 \\
\hline $\mathrm{CuL}_{2}$ & $20.06 \pm 0.04$ & 11.35 & $20.37 \pm 0.05$ & - \\
\hline $\mathrm{CuL}_{2} \mathrm{H}_{-1}$ & $8.71 \pm 0.07$ & - & - & - \\
\hline
\end{tabular}

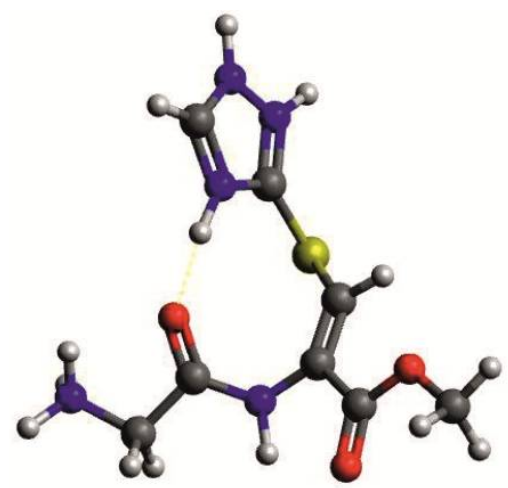

Figure 1. The proposed structure of the fully protonated 9a ligand.

The coordination studies of $9 \mathrm{a}$ and 10a were performed for two systems of different ligand-to-copper(II) ion molar ratio, namely 1:1 and 2:1. For the 10a the precipitation was observed in the $\mathrm{pH}$ range of 4.5 and 8.0 (Figure 2, panel A) and thus the study for this ligand was focused on two ranges of $\mathrm{pH}: 2-4.5$ and 8.5-10.0. It is worth to mention that the comparison of the potentiometric and spectroscopic results received for both $9 \mathrm{a}$ and 10a showed the same coordination pattern.

In the equimolar conditions at $\mathrm{pH}$ range between 3.0 and 10.0, five complexes exist with the $\mathrm{CuLH}_{\mathrm{x}}$ and $\mathrm{Cu}_{2} \mathrm{~L}_{2} \mathrm{H}_{\mathrm{x}}$ stoichiometries (Figure 2, panel A, Table 2). The coordination begins around $\mathrm{pH} 3.0$ with the formation of the $\mathrm{CuH}_{2} \mathrm{~L}$ complex. Its appearance is related to the dissociation of one proton from the ligand. Because of their low concentration in the solution, it was not possible to receive the spectroscopic parameters. Nevertheless, the corrected stability constant $\left(\log \beta=\log \beta_{\mathrm{CuLH} 2}-\log \beta_{\mathrm{H} 2 \mathrm{~L}}\right)$ equal 5.47 supports involvement of the $\mathrm{N}$-terminal amino group and formation of the species with the $\left\{\mathrm{N}_{-\mathrm{NH} 2}, \mathrm{O}_{-\mathrm{CO}}\right\}$ binding mode, which is characteristic for the linear peptides with free $N$-terminal groups [31-33]. With the increase of the $\mathrm{pH}$ the next monomeric $\mathrm{CuL}$ species appears, what significantly influences the spectral characteristics of the system with the 9a ligand (Figure 2, panel A). The location of the d-d band at $593 \mathrm{~nm}$ with molar extinction coefficient $\varepsilon=73 \mathrm{M}^{-1} \mathrm{~cm}^{-1}$ supports binding of two nitrogen donors to the metal ion. Moreover, the location of the 
CT band in the UV-Vis at $430 \mathrm{~nm}$ supports coordination of the sulfur donor. Its creation results from the release of two protons from the $\mathrm{CuLH}_{2}$. There are two possibilities of the course of this process: (i) both protons dissociate from the triazole ring or (ii) one proton derives from triazole ring and the second one from the peptide bond. Thus, the $\mathrm{CuL}$ system may be described either by the $\left\{\mathrm{N}_{-\mathrm{NH} 2}, \mathrm{~N}_{\text {triazole }}, \mathrm{S}\right\}$ or $\left\{\mathrm{N}_{-\mathrm{NH} 2}, \mathrm{~N}_{\text {amide }}, \mathrm{S}\right\}$ binding modes, respectively. The simultaneous coordination of the S-donor and deprotonated $\mathrm{N}_{\text {triazole }}$ would create the four-member chelating ring what is less thermodynamically favorable than the formation of the five-member ring, which is expected in the case of $\mathrm{N}_{\text {amide }}$ binding. Due to this, and in relation to the already known coordination abilities of the dehydrodipeptides [34], the $\left\{\mathrm{N}_{-\mathrm{NH}}, \mathrm{N}_{\text {amide }}, \mathrm{S}\right\}$ coordination manner is more probable. Based on this assumption, one of the triazole nitrogen atoms is still protonated. The value of $\log \beta_{\mathrm{CuL}}$, independent of the $\log K_{\text {triazole }}: \log \beta^{*}=\log \beta_{\mathrm{CuL}}-\log K_{\mathrm{HL}}$ is equal to 4.09 and is significantly higher than $\log \beta=2.19$ calculated for the analogous Gly(Z) $\Delta$ Phe species with the $\left\{\mathrm{N}_{-\mathrm{NH} 2}, \mathrm{~N}_{\text {amide }}\right\}$ binding mode [34]. It strongly supports the involvement of the sulfur atom and formation complex where $\mathrm{N}_{-\mathrm{NH}}, \mathrm{N}_{\text {amide, }}$ and $\mathrm{S}$ donors are placed within the plane (Figure 3a). The formation of the last, $\mathrm{CuLH}_{-1}$ complexes in both systems (with the 9a and 10a ligands) does not influence significantly the spectral abilities. The value of the $\log K$ for the formation of the $\mathrm{CuLH}_{-1}$ is comparable to the constants related to the proton dissociation from the second triazole nitrogen from the free ligands (Table 2). It strongly supports that this process does not influence the coordination mode of the copper(II) ion.
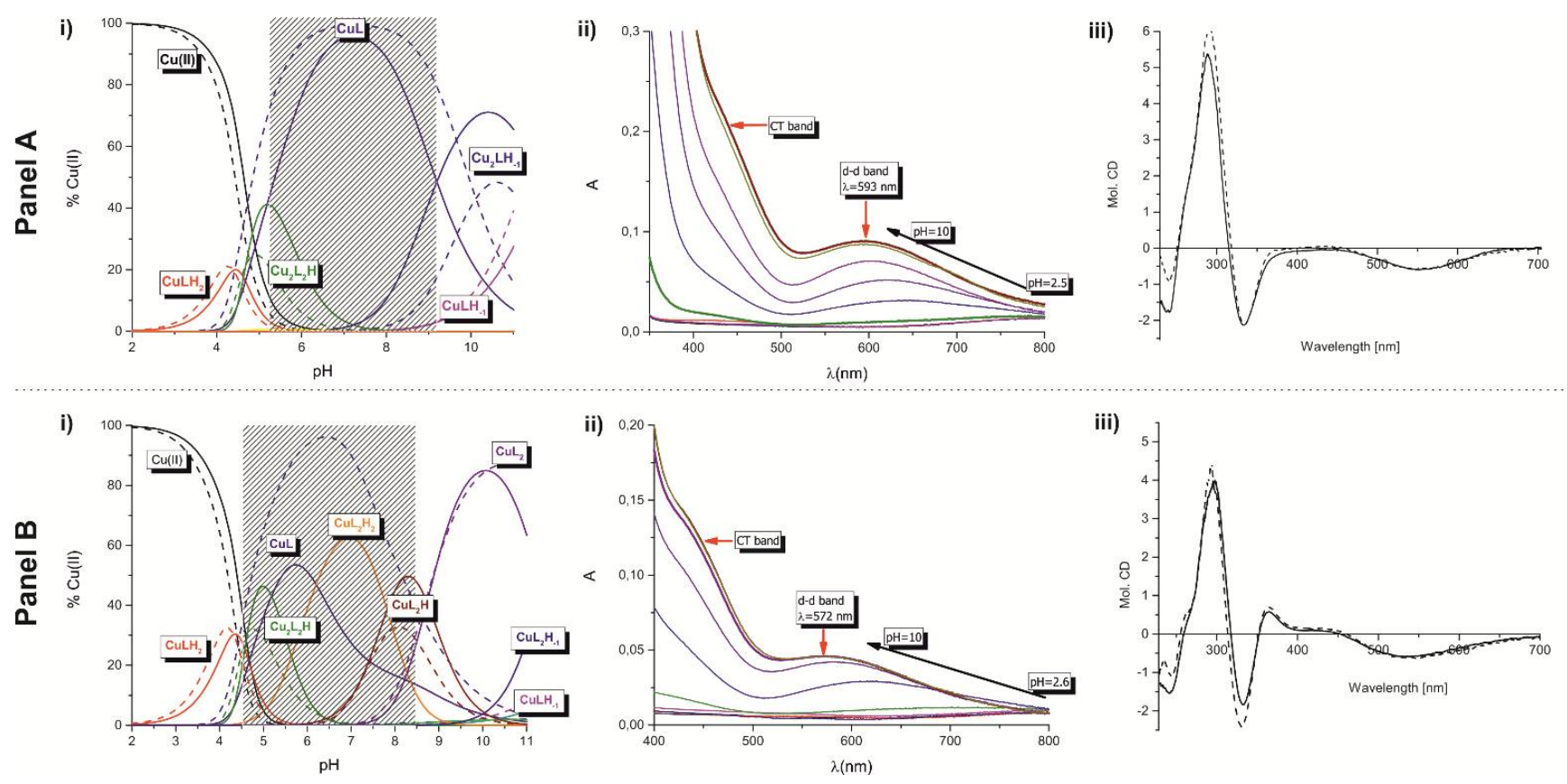

Figure 2. Panel A: (i) the species distribution curves for the 9a-Cu(II) system (solid line) and 10a-Cu(II) (dashed line) in dependence on $\mathrm{pH}$, measured for the $\mathrm{nL}: \mathrm{nCu}(\mathrm{II})=1: 1$ molar ratio, (ii) the UV-Vis spectra in dependence on $\mathrm{pH}$ for the $9 \mathrm{a}$, (iii) the CD (dashed line) and MCD (solid line) spectra of 10a with the $\mathrm{nL}: \mathrm{nCu}(\mathrm{II})=1: 1$ molar ratio at $\mathrm{pH}=10.5$. Panel B: (i) the species distribution curves for the $9 \mathrm{a}-\mathrm{Cu}$ (II) (solid line) and $10 \mathrm{a}-\mathrm{Cu}(\mathrm{II})$ (dashed line) system in dependence on $\mathrm{pH}$, measured for the $\mathrm{nL}: \mathrm{nCu}(\mathrm{II})=2: 1$ molar ratio, (ii) the UV-Vis spectra in dependence on $\mathrm{pH}$ for the 9a, (iii) the CD (dashed line) and MCD (solid line) spectra of $10 a$ with the $\mathrm{nL}: \mathrm{nCu}(\mathrm{II})=2: 1$ molar ratio at $\mathrm{pH}=10.5$.

Compounds 9 a as well as $10 a$ also form complexes with the $\mathrm{Cu}_{2} \mathrm{~L}_{2} \mathrm{H}_{\mathrm{X}}$ stoichiometry: $\mathrm{Cu}_{2} \mathrm{~L}_{2} \mathrm{H}$ and $\mathrm{Cu}_{2} \mathrm{~L}_{2} \mathrm{H}_{-1}$, with their highest concentrations being observed at $\mathrm{pH} 5.5$ and 10.5 , respectively. Both of them are created by the interaction between two mononuclear species (CuHL $\left.+\mathrm{CuL} \rightarrow \mathrm{Cu}_{2} \mathrm{~L}_{2} \mathrm{H}, \mathrm{CuL}+\mathrm{CuLH}_{-1} \rightarrow \mathrm{Cu}_{2} \mathrm{~L}_{2} \mathrm{H}_{-1}\right)$. Their appearance is related to the triazole protonation states and seems to support the assumption that it is the result of the formation of intermolecular hydrogen bonds involving $\mathrm{H}_{\text {triazoles }}$. Additionally, 
the observation that there is no significant change in the spectral abilities of the system with dominating $\mathrm{Cu}_{2} \mathrm{~L}_{2} \mathrm{H}_{-1}$, suggest the same coordination mode as in the case of $\mathrm{CuL}$ complexes (Figure 2, panel A). In the case of 10a ligand, which $N$-terminal amino acid is chiral, there was possible to extend the studies by using CD technique. Studies were carried out at $\mathrm{pH}$ of 10.5. Owing to the fact, that this molecule possesses the aromatic system, also the magnetic circular dichroism was applied to record the $\mathrm{MCD}_{\mathrm{pH} 10.5}$ spectrum, however it did not bring additional information. Anyway, the positive CT band at $290 \mathrm{~nm}$ and the negative at $344 \mathrm{~nm}$ (Figure 2, panel A) confirm the presence of two nitrogen donors: $\mathrm{N}_{-\mathrm{NH}}$, $\mathrm{N}_{\text {amide, }}$ in copper(II) coordination sphere.

Summing up, 9a and 10a show similar binding abilities, but the presence of the phenylalanine in the structure of the latter enhances the efficiency of $\mathrm{Cu}$ (II) binding. Below $\mathrm{pH} 5$ the 10a is significantly more effective binder of $\mathrm{Cu}(\mathrm{II})$ but with the increase of the solution basicity, the efficiency of copper(II) coordination of both ligands slowly equals (Figure 3b).
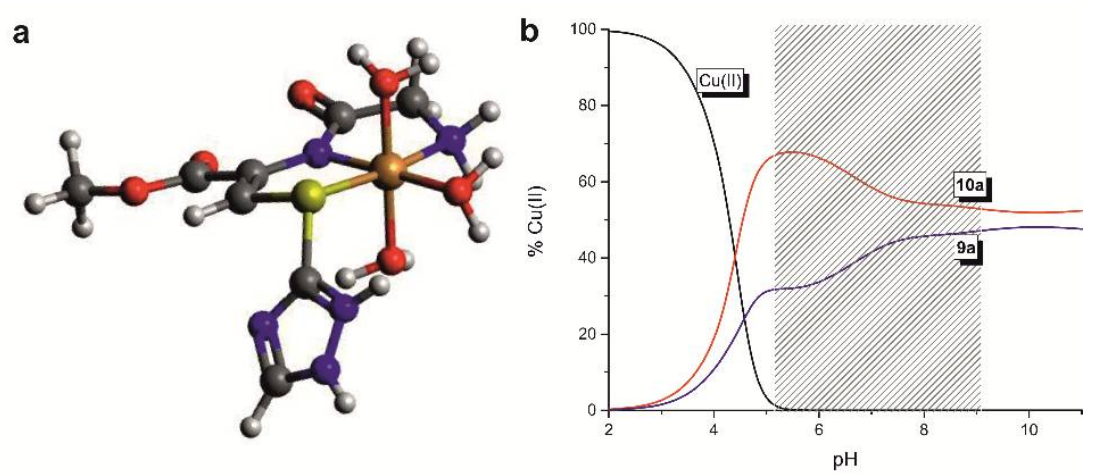

Figure 3. (a) The proposed structure of the CuL species formed by the $9 a,(b)$ the competition diagram for the $9 \mathbf{a}: \mathrm{Cu}(\mathrm{II}): \mathbf{1 0 a}$ system with the $\mathrm{nL1}: \mathrm{nCu}(\mathrm{II}): \mathrm{nL} 2=1: 1: 1$ molar ratio.

As the next, the studies of the system with the double excess of ligands have been performed (Figure 2 panel B). The analysis of the potentiometric and spectroscopic results show that both compounds, $9 \mathbf{a}$ and 10a, begin copper(II) binding by the creation of the same complexes as it was discussed above. The complexes with $\mathrm{CuL}_{2} \mathrm{H}_{\mathrm{x}}$ stoichiometry appear above $\mathrm{pH} 6.5$ (for the $9 \mathrm{a}$ ) and $\mathrm{pH} 8.5$ (for the 10a). In the system with 9a ligand any significant changes in the spectral abilities of the system are not observed, what strongly supports that: (i) the binding mode of $\mathrm{Cu}$ (II) is the same in these complexes and (ii) theirs formation is related to triazole's protons dissociation. The comparison of the location of the $\mathrm{d}-\mathrm{d}$ band in the previous system shows a blue shift $\left(\lambda_{\max 1: 1}=593 \mathrm{~nm} \rightarrow \lambda_{\max 2: 1}=572 \mathrm{~nm}\right.$, Figure 2). It confirms coordination of the third nitrogen donor to the metal ion. Moreover, the positive LMCT transition at $364 \mathrm{~nm}$ strongly supports the presence of sulphur in the coordination sphere of $\mathrm{Cu}(\mathrm{II})$. The most likely is the formation of the complex with the $\left\{2 \mathrm{xN}_{-\mathrm{NH}}, \mathrm{N}_{\text {amide, }} \mathrm{S}\right\}$ binding mode (Figure $\left.4 \mathrm{a}\right)$.

For a better understanding of the discussed system, the EPR spectrum was recorded at $\mathrm{pH} 10.5$ for the 9a with 2:1 ligand-to-metal molar ratio (Figure $4 \mathrm{~b}$ ). The observed $\mathrm{A}_{\mathrm{II}}=192$ [G] $\mathrm{g}_{\mathrm{II}}=2.199$ are relatively high but the seven lines in the high-field region of spectrum strongly confirm binding of three nitrogen donors, while the components of $g$ tensor $\left(\mathrm{g}_{z}>>\right.$ $\left.\mathrm{g}_{\mathrm{y}}, \mathrm{g}_{\mathrm{x}}>2.0023\right)$ supports the axial symmetry. Moreover, the characteristic $\mathrm{A}_{\mathrm{II}} \mathrm{Cuv}>>\mathrm{vA}_{\perp} \mathrm{Cu}$ splitting pattern suggests the $d_{x 2-y 2}$ ground state [35]. 
a

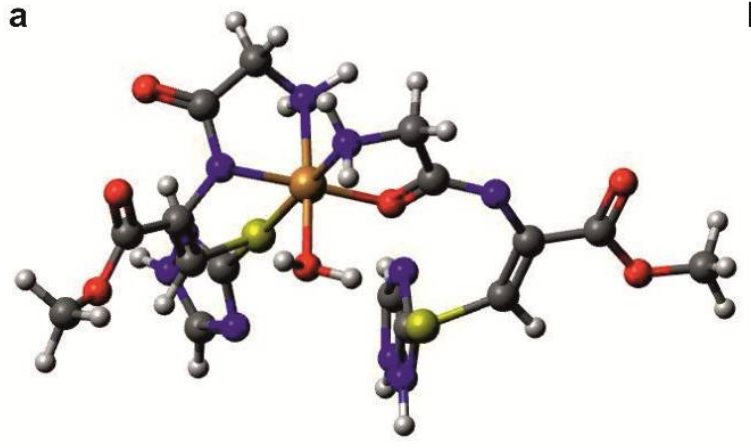

b

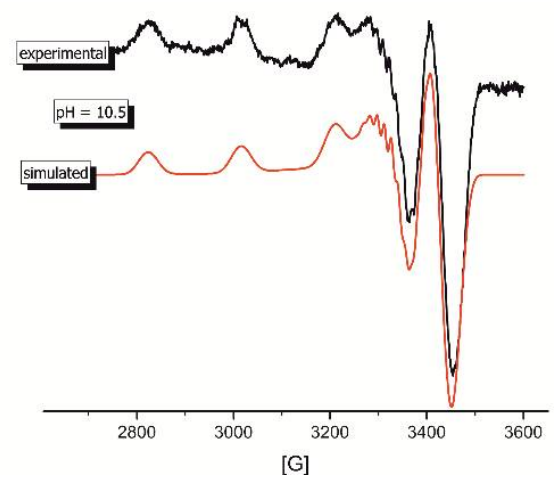

C

\begin{tabular}{|c|c|}
\hline $\mathrm{pH}=10.5$ & Parameters \\
\hline$g_{z}(g)$ & 2.199 \\
\hline$g_{y}(g)$ & 2.052 \\
\hline$g_{x,}\left(g_{-}\right)$ & 2.040 \\
\hline$A_{z}^{c_{u}}(A)^{*}$ & 192 \\
\hline$A_{x}^{c u}, A_{y}^{c_{u} u}\left(A_{-}\right)^{n}$ & 22 \\
\hline
\end{tabular}

Figure 4. (a) The proposed binding mode of the $9 a-C u(I I)$ in the complexes with the $\mathrm{CuL}_{2} \mathrm{H}_{\mathrm{x}}$ stoichiometry (b) the experimental and simulated EPR spectra and (c) parameters obtained for the 9a ligand in the system with $\mathrm{nL}: \mathrm{nCu}(\mathrm{II})=2: 1$ molar ratio and $\mathrm{pH}=10.5$.

As it was observed previously for the system of 1:1 stoichiometry the presence of phenylalanine residue evidently influenced the efficiency of the copper(II) binding in the acidic conditions. In ligand to $\mathrm{Cu}$ (II) ions of 2:1 molar ratio, the presence of the aromatic ring in the side chain effectively hinders the formation of the complexes with the $\mathrm{CuL}_{2} \mathrm{H}_{\mathrm{x}}$ stoichiometry and promotes the formation of the $\mathrm{CuL}$ complex. This ability of the 10a may be related to the protection of one of the axial positions in the coordination sphere of the $\mathrm{Cu}$ (II) by the side chain of phenyl residue.

Compounds 9a and 10a might be considered as dipeptides containing C-terminal mimetics of dehydrophenylalanine. Insertion of a dehydroamino acid residue into a sequence of peptide changes considerably the binding abilities of peptide ligands towards copper(II) ions [32-34]. The presence of the double bond influences acidity of vicinal amide function and thus the binding of amide nitrogen is favored, which makes the dehydropeptides bind metal ions significantly more effectively. Additionally, type of geometric isomer has a critical impact on the coordination equilibria, with $(Z)$ isomers being more effective ligands. The comparison of the binding abilities between $9 a$ and $\mathrm{Gly}(\mathrm{Z})$ Phe (Figure 5a) shows that at $\mathrm{pH}$ 7.4, both peptides form complexes via utilization of two nitrogens donors: $\mathrm{N}$-terminal amino group and an amide. However, due to the presence of the additional donor, sulfur atom, the ligand $\mathbf{9 a}$ is significantly more effective in $\mathrm{Cu}$ (II) coordination (Figure 5b). Thus, newly synthesized dehydropeptides $\mathbf{9 a}$ and 10a represent a new type of complexones for metal ions and thus could be utilized in the design and production of artzymes
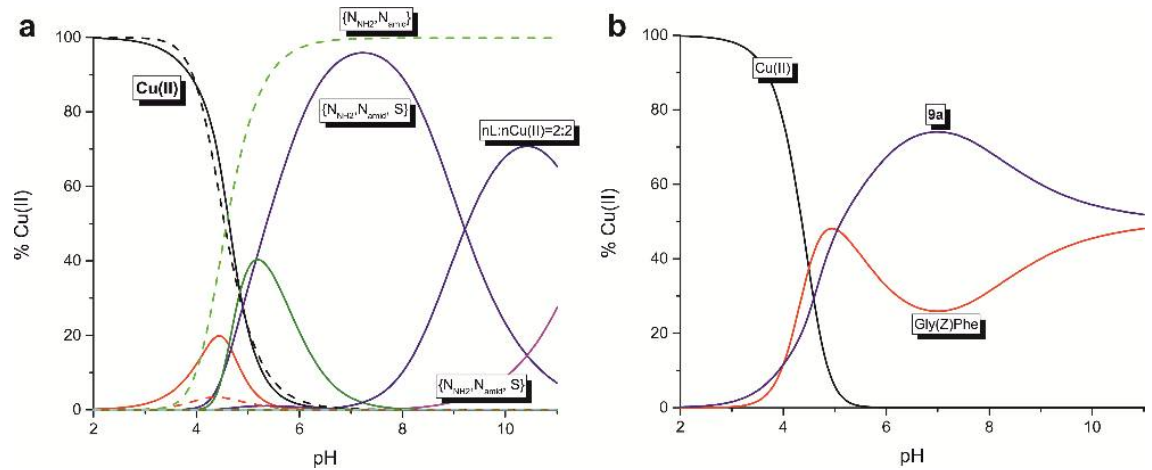

Figure 5. The comparison of: (a) formation of subsequent complexes for 9a (solid line) and Gly(Z)Phe (dashed line) in dependence on $\mathrm{pH},(\mathbf{b})$ efficiency in copper(II) binding for the $\mathrm{n}_{\mathrm{L}}: \mathrm{n}_{\mathrm{Cu}(\mathrm{II})}=1: 1$ molar ratio. 


\subsection{Antiproliferative Activity of Synthesized Compounds}

Since the dehydropeptides reveal variable biological activity, we decided to screen the synthesized compounds for antiproliferative activity in cellulo utilizing ten diverse human cancer cells lines and murine non-tumorigenic cell line (Balb/3T3). The results shown in Tables 3 and 4 indicated that most of the compounds exhibited promising activities in comparison to widely used anticancer agent cisplatin (CDDP). In Table 3, results obtained for the following cell lines are shown: breast adenocarcinoma MCF-7, breast carcinoma MDA-MB-231, lung carcinoma A549, colorectal adenocarcinoma LoVo, and its doxorubicinresistant variant $\mathrm{LoVo}^{\mathrm{DX}}$. Table 4 presents the results obtained for UM-UC-3 urinary bladder transitional cell carcinoma and its variants resistant to cisplatin, gemcitabine, vinblastine, and the cell line resistant both to cisplatin and gemcitabine.

Table 3. Antiproliferative activity of compounds 6, 7, 9 and 10 on five human cancer cell lines and non-tumorigenic line Balb/3T3 given as $\mathrm{IC}_{50} \pm \mathrm{SD}(\mu \mathrm{M})$, with cisplatin (CDDP) used as reference.

\begin{tabular}{ccccccc}
\hline Cpd. & MCF-7 & MDA-MB-231 & A-549 & LoVo & LoVo $^{\text {DX }}$ & Balb/3T3 \\
\hline 6b & $31.8 \pm 7.8$ & $35.0 \pm 10.0$ & $27.2 \pm 7.7$ & $32.4 \pm 2.6$ & {$[\mathrm{a}]$} & $38.4 \pm 3.5$ \\
6c & $5.3 \pm 0.9$ & $5.0 \pm 0.8$ & $6.2 \pm 1.4$ & $8.7 \pm 1.1$ & $6.4 \pm 0.4$ & $5.3 \pm 1.2$ \\
6d & $4.5 \pm 0.5$ & $6.1 \pm 0.6$ & $5.6 \pm 0.9$ & $6.7 \pm 0.7$ & $6.2 \pm 0.6$ & $5.8 \pm 0.9$ \\
7a & $74.5 \pm 5.8$ & $53.3 \pm 5.5$ & $60.7 \pm 12.1$ & $75.8 \pm 6.5$ & {$[\mathrm{a}]$} & $19.7 \pm 1.9$ \\
$\mathbf{7 b}$ & $15.5 \pm 2.5$ & $15.2 \pm 4.4$ & $12.0 \pm 4.0$ & $16.4 \pm 1.7$ & $23.0 \pm 2.2$ & $7.6 \pm 0.9$ \\
7c & $4.5 \pm 0.4$ & $7.1 \pm 0.8$ & $4.0 \pm 1.1$ & $6.3 \pm 0.5$ & $4.5 \pm 0.4$ & $5.3 \pm 0.4$ \\
7d & $6.8 \pm 0.5$ & $10.8 \pm 0.4$ & $6.6 \pm 1.4$ & $9.6 \pm 0.9$ & $8.6 \pm 0.9$ & $3.1 \pm 0.6$ \\
7e & $100.8 \pm 11.3$ & $74.5 \pm 7.7$ & {$[\mathrm{a}]$} & $81.7 \pm 12.4$ & {$[\mathrm{a}]$} & {$[\mathrm{a}]$} \\
$\mathbf{9 d}$ & {$[\mathrm{a}]$} & $56.0 \pm 7.1$ & $33.4 \pm 6.4$ & {$[\mathrm{~b}]$} & {$[\mathrm{b}]$} & {$[\mathrm{b}]$} \\
$\mathbf{1 0 d}$ & $22.0 \pm 4.5$ & $24.4 \pm 3.0$ & $14.0 \pm 5.6$ & $70.3 \pm 21.5$ & $33.1 \pm 9.0$ & $42.2 \pm 9.3$ \\
CDDP & $6.0 \pm 2.2$ & $24.4 \pm 4.8$ & $2.7 \pm 1.0$ & $4.4 \pm 0.3$ & $3.4 \pm 0.2$ & $10.2 \pm 4.8$ \\
\hline
\end{tabular}

[a] $\mathrm{IC}_{50}$ exceeds highest concentration used $(100 \mu \mathrm{M}),[\mathrm{b}]$ not tested.

Table 4. Antiproliferative activity of studied compounds on urinary bladder transitional cell carcinoma cell line (UM-UC-3) and its variants resistant to cisplatin (CDDP), gemcitabine (GEM), both gemcitabine and cisplatin(CDDP/GEM) and vinblastine (VBL). Results are given as $\mathrm{IC}_{50} \pm \mathrm{SD}(\mu \mathrm{M})$, with cisplatin (CDDP) used as reference.

\begin{tabular}{cccccc}
\hline Cpd. & UM-UC-3 & $\begin{array}{c}\text { UM-UC- } \\
\text { 3 CDDP }\end{array}$ & $\begin{array}{c}\text { UM-UC- } \\
\text { 3 GEM }\end{array}$ & $\begin{array}{c}\text { UM-UC- } \\
\text { 3 CDDP/GEM }\end{array}$ & $\begin{array}{c}\text { UM-UC- } \\
\mathbf{3}^{\text {VBL }}\end{array}$ \\
\hline $\mathbf{6 b}$ & $23.1 \pm 2.6$ & $34.6 \pm 3.6$ & $35.1 \pm 2.8$ & $32.5 \pm 4.0$ & $33.8 \pm 2.6$ \\
$\mathbf{6 c}$ & $7.2 \pm 0.6$ & $7.8 \pm 0.7$ & $5.2 \pm 0.6$ & $8.6 \pm 1.4$ & $6.0 \pm 1.5$ \\
$\mathbf{6 d}$ & $4.6 \pm 0.4$ & $6.4 \pm 0.4$ & $4.6 \pm 0.5$ & $6.2 \pm 0.8$ & $4.9 \pm 0.8$ \\
$\mathbf{7 a}$ & $56.0 \pm 5.7$ & $67.7 \pm 3.9$ & $65.2 \pm 4.9$ & $62.2 \pm 5.3$ & $54.9 \pm 3.5$ \\
$\mathbf{7 b}$ & $13.5 \pm 4.5$ & $19.0 \pm 3.2$ & $19.9 \pm 3.3$ & $17.2 \pm 2.1$ & $17.3 \pm 1.7$ \\
$\mathbf{7 c}$ & $6.2 \pm 0.8$ & $6.8 \pm 0.8$ & $7.0 \pm 0.5$ & $5.9 \pm 0.4$ & $5.8 \pm 0.6$ \\
$\mathbf{7 d}$ & $6.7 \pm 1.4$ & $11.2 \pm 1.5$ & $8.0 \pm 2.3$ & $9.1 \pm 1.2$ & $6.3 \pm 1.0$ \\
$\mathbf{1 0 d}$ & $30.5 \pm 3.7$ & $16.6 \pm 2.5$ & $67.8 \pm 9.6$ & $25.3 \pm 8.0$ & $9.4 \pm 2.2$ \\
CDDP & $2.4 \pm 0.6$ & $26.1 \pm 1.8$ & $2.6 \pm 0.2$ & $25.1 \pm 1.9$ & $2.3 \pm 0.3$ \\
\hline
\end{tabular}

Selected compounds exhibited high antiproliferative activity with $\mathbf{6 c}$ and $\mathbf{6 d}$ and $7 \mathrm{c}$ and $\mathbf{7 d}$ recognized as the most potent representatives for glycine and phenylalanine derivatives, respectively. In both groups, derivatives containing triazole (6a and $7 \mathbf{a})$ and adenine (6e and 7e) showed markedly lower, if any, activity. These two observations clearly indicate that $\mathrm{N}$-terminal amino acid (glycine or phenylalanine) has negligible influence on activity in contrast to $C$-terminal dehydrocysteine for which significant changes in antiproliferative activity versus structure of side chain were observed. $N$-Boc deprotection in compounds 9 and $\mathbf{1 0}$ was accompanied by a dramatic decrease in antiproliferative activity, which is an expected result of the introduction of free $-\mathrm{NH}_{2}$ group to the compound that most likely is not influxed by any specialized transporter. No cell line specificity was observed for any of compounds tested, including non-tumorigenic Balb/3T3 cell line and cell lines 
characterized by drug-resistant phenotype. Comparable activity of the studied compounds against LoVo, UM-UC-3, LoVo ${ }^{\mathrm{DX}}$ and UM-UC-3 ${ }^{\mathrm{VBL}}$ (last cell lines characterized by high P-gp expression [36]) strongly suggests that studied dipeptides of S-substituted dehydrocysteine are not substrates for multidrug resistance pumps. Their comparable activity on cisplatin-resistant cell lines characterized inter alia by increased reduced glutathione level, which in turn result in increased inactivation of electrophilic moieties indicates that these compounds are not a subject of II phase detoxification enzyme systems.

The previous report on the structure-activity relationship of structurally simple dehydroamino acids derivatives (dehydroalanine, dehydroaminobutyric acid, and dehydrophenylalanine) containing a variety of $\mathrm{N}$-protection revealed that toxicity on the selected human cancer cell lines is related to their lipophilicity and the electron-withdrawing effect of protecting group. Moreover, the results of the biochemical tests performed for selected compounds indicate that caspase-dependent apoptosis is a crucial component of their mode of action [18]. The comparison of toxicity of dehydroamino acid derivatives against lung carcinoma cell line (A549) shows that the most of the S-substituted dehydrocysteine dipeptides presented in this paper seem to be more effective (Table $3 \mathrm{vs}$. literature $\mathrm{IC}_{50}>62.5 \mu \mathrm{M}$ ) [18]. It is also worth mentioning that compound $10 \mathrm{~d}$ is more effective against resistant cell lines (with exception of one resistant to gemcitabine) as compared to the parent cell line. Compounds $\mathbf{6 c}, \mathbf{6 d}, \mathbf{7 c}$, and $\mathbf{7 d}$ are equipotential towards both resistant and parent cell lines. The exact mechanism of action of these structurally modified dehydropeptides is unknown, and extensive studies on its determination are underway. Further studies will also be conducted to assess the validity of these compounds as potential anticancer agents.

\section{Materials and Methods}

\subsection{General Procedure for Preparation of Dipeptides Containing S-Substituted Dehydrocysteine}

The peptide substrate containing Z-bromodehydroalanine (4 or 5, 1 eq) was dissolved in acetonitrile then appropriate thiol (1.05 eq) and $\mathrm{K}_{2} \mathrm{CO}_{3}(2 \mathrm{eq})$ were added. The reaction mixture was stirred at ambient temperature until the peptide substrate was consumed (controlled by TLC, usually $1-2 \mathrm{~h}$ ). The volatile components of the reaction mixture were removed by rotary evaporator. The residue was purified by flash chromatography. The product was crystallized or precipitated from the appropriate solvent mixture. Detailed information, including amounts used as well characterization of synthesized compounds, is given in Supplementary Materials.

\subsection{General Procedure for Boc Deprotection}

The dipeptide was stirred with the solution of $\mathrm{HCl}$ in methanol $(1.5 \mathrm{M})$ for $1-2 \mathrm{~h}$ at ambient temperature. The conversion of the substrate was monitored by TLC. If necessary, the reaction mixture was decolorized with activated carbon. The volatile component was co-evaporated with toluene and DCM under reduced pressure. Finally, the product was lyophilized from aqueous solution (for details please see SM).

\subsection{Potentiometric Titration}

The $\mathrm{pH}$-metric measurements were performed on Metrohm 905 Titrando system equipped with combined Biotrop ${ }^{\circledR}$ electrode. The titrant was $0.1 \mathrm{M} \mathrm{KOH} \mathrm{(Merck,} \mathrm{Germany)}$ freed of $\mathrm{CO}_{2}$ by bubbling Ar gas for $3 \mathrm{~h}$. The electrode calibration was performed before each titration. The volume of all the samples was $1.5 \mathrm{~mL}$ and the measurements were carried out at a range of $\mathrm{pH}$ of 2.5-11.0 in thermostated vessels at $298 \mathrm{~K}$ in an inert atmosphere of Ar gas. The ligands 9a and 10a were diluted in hydrochloric acid $(\mathrm{pH}=2.5)$, prepared from $37 \% \mathrm{HCl}$ (Sigma-Aldrich, Poland). Their concentration was set up at a range of 1.0-2.0 $\times 10^{-3} \mathrm{M}$ and the ionic strength of $0.1 \mathrm{M}$ was achieved by the addition of $\mathrm{KCl}$ (Sigma-Aldrich, Poland). The ligand-metal ion systems were prepared by addition of $\mathrm{CuCl}_{2}$ (Sigma-Aldrich, Poland). stock solutions to reach final ligand to metal ratio (nL: $\mathrm{nCu}^{2+}$ ) being 2:1 or 1:1. 
The protonation $\left(\beta_{\mathrm{i}}=\left[\mathrm{H}_{\mathrm{i}} \mathrm{L}\right] /\left[\mathrm{H}^{+}\right]^{\mathrm{i}}[\mathrm{L}]\right)$, stability constants $\left(\beta_{\mathrm{pqr}}=\left[\mathrm{M}_{\mathrm{p}} \mathrm{H}_{\mathrm{q}} \mathrm{L}_{\mathrm{r}}\right] /[\mathrm{M}]^{\mathrm{p}}[\mathrm{H}]^{\mathrm{q}}[\mathrm{L}]^{\mathrm{r}}\right)$, and stoichiometry of complexes were calculated using the HYPERQUAD program [37]. The distribution species plots were made by HySS program [38]. The standard deviations were computed for all the constants and indicated the presence of only random errors, which was a good evidence of the presence of each species in the equilibrium.

\subsection{Spectroscopic Measurements (UV-Vis, CD, EPR)}

The UV-Vis absorption measurements were recorded on Varian Carry 50 Bio spectrophotometer. All spectra were collected in a quartz cuvette with $1 \mathrm{~cm}$ path length at $298 \mathrm{~K}$. The spectral range was 300-800 $\mathrm{nm}$ with resolution $0.1 \mathrm{~nm}$. The molar extinction coefficients $\left(\varepsilon\left[\mathrm{M}^{-1} \mathrm{~cm}^{-1}\right]\right)$ were calculated for each spectrum at a wavelength of maximum absorption.

The Circular Dichroism spectra (CD) and Magnetic Circular Dichroism (MCD) were measured on a JASCO J 600 spectropolarimeter in a range of 230-800 nm with $0.1 \mathrm{~nm}$ resolution. The optical length of the quartz cuvettes was $10 \mathrm{~mm}$. The molar circular dichroism coefficient $\left(\Delta \varepsilon\left[\mathrm{M}^{-1} \mathrm{~cm}^{-1}\right]\right)$ was calculated for each spectrum.

The Electron Paramagnetic Resonance (EPR) spectra were recorded on a Brucker ESP 300E spectrometer at X-band frequency $(9.5 \mathrm{GHz})$ at $77 \mathrm{~K}$ obtained by the use of liquid nitrogen. The procedure of sample preparation for spectroscopic measurements was the same as in potentiometric titration. The EPR samples were protected by adding $30 \%$ of ethylene glycol (Sigma-Aldrich, Poland). The $\mathrm{pH}$ of the samples was determined by adding a small quantity of a concentrated solution of $\mathrm{KOH}$ (Merck, Germany) to achieve the desired value and controlled by Mettler Toledo $\mathrm{pH}$-meter equipped with combined electrode InLab ${ }^{\circledR}$ Micro. The simulation of the EPR spectrum was performed by the Hyperfine Spectrum program written by W.R. Hagen [39].

\subsection{Visualization of Complex Structures}

The proposed structures of complexes were drawn and optimized by using Avogadro: an open-source molecular builder and visualization tool, version 1.2.0 (http:/ / avogadro. cc/) using universal field force [40].

\subsection{Antiproliferative Activity Assessment}

\subsubsection{Cell Lines and Cultures Conditions}

Ten different human cancer cell lines (including drug-resistant sublines) and one non-tumorigenic murine fibroblasts cell line were used to determine antiproliferative activity of the tested compounds. The MDA-MB-231 (breast adenocarcinoma), UM-UC-3 (urinary bladder transitional cell carcinoma), LoVo (colorectal adenocarcinoma), LoVo ${ }^{\mathrm{Dx}}$ (colorectal adenocarcinoma, doxorubicin-resistant) and Balb/3T3 (non-tumorigenic murine fibroblasts) were purchased from the American Type Culture Collection (ATCC; Rockville, USA). The MCF-7 (breast adenocarcinoma) and A549 (lung carcinoma) were purchased from European Collection of Authenticated Cell Cultures (ECACC; Porton Down, UK). The UM-UC-3 $3^{C D D P}$, UM-UC-3 ${ }^{\text {GEM }}$, UM-UC-3 ${ }^{\mathrm{VBL}}$, and UM-UC-3 ${ }^{\mathrm{CDDP}} / \mathrm{GEM}$ cell lines were established at Hirszfeld Institute of Immunology and Experimental Therapy of the Polish Academy of Sciences (HIIET, PAS, Wroclaw, Poland) by the continuous exposure to the increasing concentrations of corresponding cytostatics.

The Balb/3T3 and UM-UC-3 were cultured in Dulbecco's Modified Eagle Medium (DMEM; Life Technologies, UK) supplemented with 10\% $(v / v)$ fetal bovine serum (FBS; GE Healthcare HyClone, Logan, USA) and 2 mM L-glutamine (Sigma-Aldrich, Poznan, Poland). The UM-UC-3 CDDP ,UM-UC-3 $3^{\text {GEM }, U M-U C-3 V B L, ~ a n d ~ U M-U C-3 ~} 3^{\text {CDDP/GEM }}$ culture media were additionally supplemented with appropriate cytostatics: $2.5 \mu \mathrm{g} / \mathrm{mL}$ cisplatin (Accord, Warsaw, Poland) for UM-UC-3 CDDP , 500 nM gemcitabine (Sigma-Aldrich, Poznan, Poland) for UM-UC-3 ${ }^{\text {GEM }}, 5 \mathrm{nM}$ vinblastine (Sigma-Aldrich, Poznań, Poland) for UMUC-3VBL, $2.5 \mu \mathrm{g} / \mathrm{mL}$ cisplatin and $500 \mathrm{nM}$ gemcitabine for UM-UC-3 CDDP/GEM. The LoVo cell line was cultured in F-12K Nutrient Mixture (F-12K; Corning, Corning, USA), supplemented with $10 \%(v / v)$ FBS. LoVo ${ }^{\text {Dx }}$ culture medium was additionally supplemented 
with doxorubicin $100 \mathrm{ng} / \mathrm{mL}$ (Accord, Warsaw, Poland). The MCF-7 cell line was cultured in Eagle's medium (HIIET, PAS, Wroclaw, Poland), supplemented with $10 \%(v / v)$ FBS (Sigma-Aldrich, Poznań, Poland), 2 mM L-glutamine, MEM non-essential amino acid solution 1\% $(v / v)$ (Sigma-Aldrich, Poznań, Poland), insulin $8 \mu \mathrm{g} / \mathrm{mL}$ (Sigma-Aldrich, Poznań, Poland). The MDA-MB-231 cell line was cultured in RPMI 1640 (HIIET, PAS, Wroclaw, Poland), supplemented with 10\% (v/v) FBS (Sigma-Aldrich, Poznań, Poland) and 2 mM L-glutamine. The A 549 cell line was cultured in OptiMEM (HIIET, PAS, Wroclaw, Poland), supplemented with 5\% $(v / v)$ FBS (GE Healthcare HyClone, Logan, USA) and $2 \mathrm{mM}$ L-glutamine. All culture media were supplemented with antibiotics-100 $\mathrm{gg} / \mathrm{mL}$ streptomycin (Polfa Tarchomin, Warsaw, Poland) and $100 \mathrm{U} / \mathrm{mL}$ penicillin (Sigma-Aldrich, Poznań, Poland).

All cell lines were cultured in a humidified atmosphere at $37^{\circ} \mathrm{C}$ with $5 \%(v / v) \mathrm{CO}_{2}$ and passaged twice a week using EDTA-Trypsin solution (pH 8; HIIET, Wroclaw, Poland) as a detachment agent.

All compounds, for antiproliferative activity assessment, were stored at $80{ }^{\circ} \mathrm{C}$ as $50 \mathrm{mM}$ solutions in dimethyl sulfoxide (DMSO; Avantor Performance Materials, Gliwice, Poland).

\subsubsection{Antiproliferative Activity Assessment by Sulforhodamine B Assay}

The cells were seeded on 384-well plates (Greiner Bio One, Kremsmünster, Austria) at $1 \times 10^{3}$ cells / well density for A 549, UM-UC-3, UM-UC-3 ${ }^{\text {CDDP }}$, UM-UC-3 ${ }^{\text {GEM }}$, UM-UC$3^{\text {CVBL }}$ and UM-UC-3 ${ }^{\text {CDDP/GEM }}$ cell lines. Other cell lines were seeded at $2 \times 10^{3}$ cells/well. After overnight incubation, compounds were applied at eight concentrations (ranging from $100 \mu \mathrm{M}$ to $0.03 \mu \mathrm{M}$ ). After $72 \mathrm{~h}$ incubation, the sulforhodamine B (SRB) assay based on Skehan et al. [41] was carried out with slight modifications. In brief, $50 \mu \mathrm{L}$ of the medium was replaced with $30 \mu \mathrm{L} /$ well of $25 \%(w / v)$ trichloroacetic acid (Avantor Performance Materials, Gliwice, Poland). After $1 \mathrm{~h}$ incubation at room temperature, plates were washed three times with tap water, and $20 \mu \mathrm{L}$ of $0.1 \%(w / v)$ solution of sulforhodamine B (SigmaAldrich, Poznan, Poland) in 1\% (v/v) acetic acid (Avantor Performance Materials, Gliwice, Poland) was added to each well. After $30 \mathrm{~min}$ incubation at room temperature, the unbound dye was washed out with $1 \%(v / v)$ acetic acid. Bound dye was solubilized with $70 \mu \mathrm{L}$ of $10 \mathrm{mM}$ unbuffered TRIS (Avantor Performance Materials, Gliwice, Poland) solution. The procedure was performed using Biotek EL-406 washing station (BioTek Instruments, USA). Absorbance was read using a Biotek Hybrid H4 reader (BioTek Instruments, USA) at $540 \mathrm{~nm}$ wavelength. Crude absorbance data was used to calculate proliferation inhibition using the formula (1). Then it was used for $\mathrm{IC}_{50}$ calculations performed in (GraphPad Software, Inc.) utilizing '[Inhibitor] vs. response-Variable slope (four parameters)' model.

$$
\% \operatorname{Inh}=\left[\left(\frac{A_{p}-A_{m}}{A_{k}-A_{m}}\right) \times 100\right]-100
$$

$A_{m}$-absorbance for cell-free wells, $A_{k}$-absorbance for vehicle-treated, control wells, $A_{p}$-absorbance for compounds-treated wells

\section{Conclusions}

An efficient procedure for the synthesis of dehydropeptides containing structurally variable (Z)-dehydrocysteines was elaborated by applying readily available peptides containing (Z)- $\beta$-bromo-dehydroalanine as substrates. These peptides might be considered as building blocks for the synthesis of artificial enzymes. Peptides containing triazole in the side chain appeared to be novel complexones of $\mathrm{Cu}^{2+}$ ions. Additionally, the dipeptides 6 and 7 exhibited potent antiproliferative properties against cancer cell lines, including lines resistant to the action of known anticancer agents. 
Supplementary Materials: The following are available online at https:/ / www.mdpi.com/1422-006 7/22/4/2168/s1, General Information; Discussion of NMR analysis; Figure S1: ${ }^{13} \mathrm{C}$ NMR spectra for dipeptide 6e containing adenine residue performed with different experimental time; Figure S2: NOE difference NMR spectra for dipeptides $\mathbf{6 a}$ and 7a; Characterization of compounds: 6a-e, 7a-e, 8, 9a, 9d, 10a and 10d; ${ }^{1} \mathrm{H}$ NMR, ${ }^{13} \mathrm{C}$ NMR and IR spectra of the obtained compounds.

Author Contributions: Conceptualization, P.L., J.B., M.P. and P.K.; methodology, P.L., J.B. and M.P; validation, P.L., J.B. and M.P.; investigation, P.L., A.K., A.P., M.C. and K.P.; resources, P.K., J.B. and M.P.; data curation, P.L., J.B. and M.P; writing-original draft preparation, P.L, J.B. and M.P. writingreview and editing, P.L. and P.K.; visualization, J.B.; supervision, P.K.; project administration, P.L. and P.K.; funding acquisition, P.K and M.P. All authors have read and agreed to the published version of the manuscript.

Funding: This research was funded by National Science Centre, Poland (NCN), grant numbers 2016/21/B/ST5/00115—recipient Paweł Kafarski and 2017/26/D/NZ7/01152—recipient Mateusz Psurski.

Institutional Review Board Statement: Not applicable.

Informed Consent Statement: Not applicable.

Data Availability Statement: All data are reported in the manuscript and in the Supplementary Material and are available from corresponding author upon request.

Acknowledgments: We wish to thank Dorota Wieczorek (NMR), Gabriela Maciejewska (HRMS), and Marek Grzymek (FT-IR) for assistance with the acquisition of analytical data and Edward Krzyżak (proposed structure of complexes).

Conflicts of Interest: The authors declare no conflict of interest.

\section{References}

1. Raynal, M.; Ballester, P.; Vidal-Ferran, A.; Van Leeuwen, P.W.N.M. Supramolecular catalysis. Part 2: Artificial enzyme mimics. Chem. Soc. Rev. 2014, 43, 1734-1787. [CrossRef]

2. Kuah, E.; Toh, S.; Yee, J.; Ma, Q.; Gao, Z. Enzyme mimics: Advances and applications. Chem. Eur. J. 2016, 22, 8404-8430. [CrossRef]

3. Okamoto, Y.; Ward, T. Supramolecular enzyme mimics. In Comprehensive Supramolecular Chemistry II, 2nd ed.; Atwood, J.L., Ed.; Elsevier: Amsterdam, The Netherlands, 2017; pp. 459-510.

4. Shi, J.; Wu, Y.; Zhang, S.; Tian, Y.; Yang, D.; Jiang, Z. Bioinspired construction of multi-enzyme catalytic systems. Chem. Soc. Rev. 2018, 47, 4295-4313. [CrossRef]

5. Raffy, Q.; Ricoux, R.; Mahy, J.-P. A new kind of eco-compatible hybrid biocatalyst for selective reactions: Artificial metalloenzymes. In Focus on Catalysis Research: New Developments, 1st ed.; Ghang, M., Ramel, B., Eds.; Nova Science Publishers Inc.: New York, NY, USA, 2011; pp. 31-62.

6. Ward, T.R. Artificial metalloenzymes based on the biotin-avidin technology: Enantioselective catalysis and beyond. Acc. Chem. Res. 2011, 44, 47-57. [CrossRef] [PubMed]

7. Legrand, B.; Aguesseau-Kondrotas, J.; Simon, M.; Maillard, L. Catalytic foldamers: When the structure guides the function. Catalysts 2020, 10, 700. [CrossRef]

8. Di Meo, T.; Ghattas, W.; Herrero, C.; Velours, C.; Minard, P.; Mahy, J.-P.; Ricoux, R.; Urvoas, A. $\alpha$ Rep A3: A versatile artificial scaffold for metalloenzyme design. Chem. Eur. J. 2017, 23, 10156-10166. [CrossRef]

9. Nanda, V.; Koder, R.L. Designing artificial enzymes by intuition and computation. Nat. Chem. 2010, 2, 15-24. [CrossRef] [PubMed]

10. Razkin, J.; Nilsson, H.; Baltzer, L. Catalysis of the cleavage of uridine 3'-2,2,2-trichloroethylphosphate by a designed helix-loop-helix motif peptide. J. Am. Chem. Soc. 2007, 129, 14752-14758. [CrossRef] [PubMed]

11. Zastrow, M.L.; Peacock, A.F.A.; Stuckey, J.A.; Pecoraro, V.L. Hydrolytic catalysis and structural stabilization in a designed metalloprotein. Nat. Chem. 2011, 4, 118-123. [CrossRef] [PubMed]

12. Drewniak, M.; Węglarz-Tomczak, E.; Ożga, K.; Rudzińska-Szostak, E.; Macegoniuk, K.; Tomczak, J.M.; Bejger, M.; Rypniewski, W.; Berlicki, Ł. Helix-loop-helix peptide foldamers and their use in the construction of hydrolase mimetics. Bioorg. Chem. 2018, 81, 356-361. [CrossRef]

13. Armstrong, C.T.; Watkins, D.W.; Anderson, J.L.R. Constructing manmade enzymes for oxygen activation. Dalton Trans. 2013, 42, 3136-3150. [CrossRef]

14. Doyle, L.; Hallinan, J.; Bolduc, J.; Parmeggiani, F.; Baker, D.; Stoddard, B.L.; Bradley, P. Rational design of $\alpha$-helical tandem repeat proteins with closed architectures. Nature 2015, 528, 585-588. [CrossRef]

15. Le Bailly, B.A.F.; Clayden, J. Dynamic foldamer chemistry. Chem. Commun. 2016, 52, 4852-4863. [CrossRef]

16. Rufo, C.M.; Moroz, Y.S.; Moroz, O.V.; Stöhr, J.; Smith, T.A.; Hu, X.; DeGrado, W.F.; Korendovych, I.V. Short peptides self-assemble to produce catalytic amyloids. Nat. Chem. 2014, 6, 303-309. [CrossRef] 
17. Siodłak, D. $\alpha, \beta$-dehydroamino acids in naturally occurring peptides. Amino Acids 2015, 47, 1-17. [CrossRef] [PubMed]

18. Videira, R.A.; Andrade, P.B.; Monteiro, L.S.; Valentao, P.; Ferreira, P.M.T.; Pereira, D.M. Toxicity and structure-activity relationship (SAR) of $\alpha, \beta$-dehydroamino acids against human cancer cell lines. Toxicol. In Vitro 2018, 47, 26-37. [CrossRef]

19. Lenartowicz, P.; Makowski, M.; Oszywa, B.; Haremza, K.; Latajka, R.; Pawełczak, M.; Kafarski, P. Addition of thiols to the double bond of dipeptide C-terminal dehydroalanine as a source of new inhibitors of cathepsin C. Biochimie 2017, 139, 46-55. [CrossRef]

20. Lenartowicz, P.; Dziuk, B.; Zarychta, B.; Makowski, M.; Kafarski, P. Michael additions to double bonds of esters of N-protected (s)phenylalanyldehydroalanine (X-(s)-Phe- $\triangle$ Ala-OMe) and its phosphonic acid counterpart (X-(s)-Phe- $\triangle \mathrm{Ala}-\mathrm{PO}(\mathrm{OEt}) 2)$. Phosphorus Sulfur Silicon Relat. Elem. 2017, 192, 706-712. [CrossRef]

21. Abreu, A.S.; Silva, N.O.; Ferreira, P.M.T.; Queiroz, M. Synthesis of novel amino acids and dehydroamino acids containing the benzo[b]thiophene moiety. Eur. J. Org. Chem. 2003, 2003, 1537-1544. [CrossRef]

22. Goren, L.; Pappo, D.; Goldberg, I.; Kashman, Y. Acyclic and cyclic thioenamino peptides: Solution- and solid-phase synthesis. Tetrahedron Lett. 2009, 50, 1048-1050. [CrossRef]

23. Matera, A.; Brasun, J.; Cebrat, M.; Świątek-Kozłowska, J. The role of the histidine residue in the coordination abilities of peptides with a multi-histidine sequence towards copper(II) ions. Polyhedron 2008, 27, 1539-1555. [CrossRef]

24. Jakab, N.I.; Gyurcsik, B.; Körtvélyesi, T.; Vosekalna, I.; Jensen, J.; Larsen, E. Design of histidine containing peptides for better understanding of their coordination mode toward copper(II) by CD spectroscopy. J. Inorg. Biochem. 2007, 101, 1376-1385. [CrossRef]

25. Myari, A.; Malandrinos, G.; Deligiannakis, Y.; Plakatouras, J.C.; Hadjiliadis, N.; Nagy, Z.; Sòvágó, I. Interaction of Cu ${ }^{2+}$ with His-Val-His and of $\mathrm{Zn}^{2+}$ with His-Val-Gly-Asp, two peptides surrounding metal ions in Cu,Zn-superoxide dismutase enzyme. J. Inorg. Biochem. 2001, 85, 253-261. [CrossRef]

26. Várnagy, K.; Szabó, J.; Sóvágó, I.; Malandrinos, G.; Hadjiliadis, N.; Sanna, D.; Micera, G. Equilibrium and structural studies on copper(II) complexes of tetra-, penta- and hexa-peptides containing histidyl residues at the C-termini. J. Chem. Soc. Dalton Trans. 2000, 467-472. [CrossRef]

27. Pettit, L.D.; Pyburn, S.; Bal, W.; Kozłowski, H.; Bataille, M. A study of the comparative donor properties to CuII of the terminal amino and imidazole nitrogens in peptides. J. Chem. Soc. Dalton Trans. 1990, 3565-3570. [CrossRef]

28. Khalil, M.M.; Mahmoud, R.; Moussa, M. The determination of the stability constants of complexes of 1,2,4-triazoles and biologically relevant ligands with M(II) by potentiometric titration in aqueous solution. J. Coord. Chem. 2012, 65, 2028-2040. [CrossRef]

29. Abdel, A.; El-Gendy, M.S.; Abdelhamid, A.O. Synthesis and antimicrobial activities of pyrido[2,3-d]pyrimidine, pyridotriazolopyrimidine, triazolopyrimidine, and pyrido[2,3-d:6,5d']dipyrimidine derivatives. Eur. J. Chem. 2012, 3, 455-460. [CrossRef]

30. Khalil, M.M.; Radalla, A.M.; Mohamed, A.G. Potentiometric investigation on complexation of divalent transition metal ions with some zwitterionic buffers and triazoles. J. Chem. Eng. Data 2009, 54, 3261-3272. [CrossRef]

31. Osz, K.; Bóka, B.; Várnagy, K.; Sóvágó, I.; Kurtán, T.; Antus, S. The application of circular dichroism spectroscopy for the determination of metal ion speciation and coordination modes of peptide complexes. Polyhedron 2002, 21, 2149-2159. [CrossRef]

32. Brasun, J.; Makowski, M.; Ołdziej, S.; Świątek-Kozłowska, J. Coordination ability of pentapeptides with two dehydro-amino acid residues inserted into their sequences. J. Inorg. Biochem. 2004, 98, 1391-1398. [CrossRef] [PubMed]

33. Świątek-Kozłowska, J.; Brasuń, J.; Chruściński, L.; Chruścińska, E.; Makowski, M.; Kozłowski, H. Impact of $\alpha, \beta$-dehydroamino acid residues on the binding abilities of di-, tri- and tetra-peptides. New J. Chem. 2000, 24, 893-896. [CrossRef]

34. Światek-Kozłowska, J.; Brasuń, J.; Łuczkowski, M.; Makowski, M. Binding abilities of dehydropeptides towards Cu(II) and Ni(II) ions. Impact of Z-E isomerization on metal ion binding. J. Inorg. Biochem. 2002, 90, 106-112. [CrossRef]

35. Pap, J.S.; Kripli, B.; Bányai, V.; Giorgi, M.; Korecz, L.; Gajda, T.; Árus, D.; Kaizer, J.; Speier, G. Tetra-, penta- and hexacoor-dinate copper(II) complexes with N3 donor isoindoline-based ligands: Characterization and SOD-like activity. Inorg. Chim. Acta 2011, 376, 158-169. [CrossRef]

36. Wesołowska, O.; Wiśniewski, J.; Środa, K.; Krawczenko, A.; Bielawska-Pohl, A.; Paprocka, M.; Dus, D.; Michalak, K. 8Prenylnaringenin is an inhibitor of multidrug resistance-associated transporters, P-glycoprotein and MRP1. Eur. J. Pharmacol. 2010, 644, 32-40. [CrossRef]

37. Gans, P.; Sabatini, A.; Vacca, A. Investigation of equilibria in solution. Determination of equilibrium constants with the HYPERQUAD suite of programs. Talanta 1996, 43, 1739-1753. [CrossRef]

38. Alderighi, L.; Gans, P.; Ienco, A.; Peters, D.; Sabatini, A.; Vacca, A. Hyperquad simulation and speciation (HySS): A utility program for the investigation of equilibria involving soluble and partially soluble species. Coord. Chem. Rev. 1999, 184, 311-318. [CrossRef]

39. Hagen, W.R. Biomolecular EPR Spectroscopy; CRC Press: Boca Raton, FL, USA, 2008.

40. Hanwell, M.D.; Curtis, D.E.; Lonie, D.C.; Vandermeersch, T.; Zurek, E.; Hutchison, G.R. Avogadro: An advanced semantic chemical editor, visualization, and analysis platform. J. Cheminform. 2012, 4, 17. [CrossRef] [PubMed]

41. Skehan, P.; Storeng, R.; Scudiero, D.; Monks, A.; McMahon, J.; Vistica, D.; Warren, J.T.; Bokesch, H.; Kenney, S.; Boyd, M.R. New colorimetric cytotoxicity assay for anticancer-drug screening. J. Natl. Cancer Inst. 1990, 82, 1107-1112. [CrossRef] [PubMed] 